\title{
Biosynthesis of Thyroglobulin
}

\author{
INCORPORATION OF [1-14C]GALACTOSE, [1-14C]MANNOSE AND [4,5-3 $\left.\mathrm{H}_{2}\right] \mathrm{LEUCINE}$ \\ INTO SOLUBLE PROTEINS BY RAT THYROIDS IN VITRO
}

\author{
BY ANNETTE HERSCOVICS \\ Department of Anatomy, McGill University, Montreal, Que., Canada
}

(Received 29 October 1968)

\begin{abstract}
1. Rat thyroid lobes were incubated for various periods of time in Krebs-Ringer bicarbonate containing $\left[{ }^{3} \mathrm{H}\right]$ leucine and either [1-14 C]galactose or [1-14 C]mannose. Radioactivity in soluble proteins was determined after their separation by sucrosegradient centrifugation. 2. The time-course of incorporation of label from $\left[{ }^{14} \mathrm{C}\right]$ mannose into soluble thyroid proteins was parallel to that observed for $\left[{ }^{3} \mathrm{H}\right]$ leucine. There was a lag of at least $30 \mathrm{~min}$. before either label appeared in non-iodinated thyroglobulin (protein 17-18s). During this time both labels were detected in two fractions known to contain subunit precursors of thyroglobulin (fractions $12 \mathrm{~s}$ and 3-8s). Radioactivity from double-labelled fractions $12 \mathrm{~s}$ and 3-8s was transferred to protein 17-18s during subsequent incubation in an unlabelled medium. 3. In contrast, most of the $\left[{ }^{14} \mathrm{C}\right]$ galactose was immediately incorporated into protein 17-18s. 4. During the first hour of incubation, puromycin almost completely inhibited the incorporation of label from $\left[{ }^{3} \mathrm{H}\right]$ leucine and $\left[{ }^{14} \mathrm{C}\right]$ mannose into all protein fractions, but had little effect on the incorporation of $\left.{ }^{14} \mathrm{C}\right]$ galactose into protein 17-18s. 5. These results indicate that mannose is incorporated into the carbohydrate groups of protein 17-18s at an earlier stage in its formation than galactose. It is suggested that the synthesis of the carbohydrate groups of thyroglobulin begins soon after formation of the polypeptide components, more than $30 \mathrm{~min}$. before these are aggregated to protein 17-18s; carbohydrate synthesis then proceeds in a stepwise manner, galactose being incorporated at about the time of aggregation of subunits to protein 17-18s. Most, if not all, the carbohydrate is added to thyroglobulin before it is iodinated.
\end{abstract}

Thyroglobulin is a soluble iodinated glycoprotein that plays a major role in the synthesis and storage of the hormones thyroxine and tri-iodothyronine. Thyroglobulin has a molecular weight of about 660000 and a sedimentation coefficient of $19 \mathrm{~s}$ (Robbins \& Rall, 1960), and probably consists of two pairs of two different polypeptide chains (Edelhoch, 1965; Lissitzky, Rolland \& Bergot, 1965a). Other thyroid proteins are referred to by their sedimentation coefficient.

Thyroglobulin can be dissociated into two halfmolecules of $12 \mathrm{~s}$ by raising the $\mathrm{pH}$ above 7 , by decreasing the salt concentration or by treatment with detergents (Edelhoch, 1960; Edelhoch \& Lippoldt, 1960). There is disagreement on the number and size of the polypeptide chains formed from thyroglobulin after complete reduction of the disulphide bonds with mercaptoethanol. This treatment would yield either four polypeptide chains of molecular weight about 165000 with a sedimentation coefficient between 3 and $8 \mathrm{~s}$ for calf thyro- globulin (De Crombrugghe, Pitt-Rivers \& Edelhoch, 1966), or five or six polypeptide chains with a molecular weight between 110000 and 125000 for human thyroglobulin (Pierce, Ravitch, Brown \& Stanley, 1965), or eight polypeptide chains of about 80000 for sheep thyroglobulin (Lissitzky, Rolland, Reynaud, Savary \& Lasry, 1968). Thyroglobulin is a complex glycoprotein containing $8-10 \%$ of carbohydrate (Ujejski \& Glegg, 1955; Lacombe \& Michel, 1955; Gottschalk \& Ada, 1956; Spiro \& Spiro, 1965a). This carbohydrate consists of 23 oligosaccharide units per molecule, of two distinct types (Cheftel, Bouchilloux \& Lissitzky, 1964; Spiro, 1965). The smaller type contains only mannose and $N$-acetylglucosamine in the ratio $5: 1$; the larger contains mannose, galactose, $N$-acetylglucosamine, sialic acid and fucose. The last-named type of carbohydrate group is a branched structure with several chains in each of which a terminal sialic acid or fucose is linked to galactose, which in turn is linked to $N$-acetylglucosamine. These

Bioch. 1969, 112 
branches are then attached to an inner core containing mannose and $N$-acetylglucosamine (Spiro \& Spiro, 1965b). The major type of linkage of the carbohydrate groups to the polypeptide chains is probably through aspartic acid, but the exact relationship between the carbohydrate groups and the thyroglobulin subunits has not been elucidated.

The biosynthesis of thyroglobulin was first investigated by Seed \& Goldberg (1963) in sheep thyroid slices in vitro. They observed that labelled amino acids are initially incorporated into protein fractions characterized as $12 \mathrm{~s}$ and 3-8 $\mathrm{s}$ by sucrose-gradient centrifugation, before any label is observed in thyroglobulin itself. After a lag of at least $20 \mathrm{~min}$. radioactivity appears in the region of thyroglobulin with a peak at 17-18s (Seed \& Goldberg, 1965; Sellin \& Goldberg, 1965). Similar observations have also been made by other authors in rat thyroid slices in vitro (Lissitzky, Roques, Torresani, Simon \& Bouchilloux, 1964; Lissitzky, Roques, Torresani \& Simon, 1965b), and in rat and guineapig thyroids in vivo (Vecchio, Salvatore \& Salvatore, 1966; Ekholm \& Strandberg, 1967a,b; Nunez, Pavlovic-Hournac, Rappaport \& Roche, 1967; Cavalieri \& Searle, 1967; Thomson \& Goldberg, 1968). The labelled protein 17-18s behaves immunologically like thyroglobulin, exhibits the same solubility characteristics as thyroglobulin and can be dissociated reversibly to $12 \mathrm{~s}$ molecules under the same conditions as thyroglobulin (Seed \& Goldberg, 1965; Sellin \& Goldberg, 1965). The labelled protein $17-18 \mathrm{~s}$ can be transformed into protein $19 \mathrm{~s}$ on iodination, whether chemical or physiological (Nunez, Mauchamp, Macchia \& Roche, 1965; Cavalieri \& Searle, 1967; Thomson \& Goldberg, 1968), and therefore represents a noniodinated form of thyroglobulin (Nunez et al. 1965). In pulse-labelling experiments with radioactive amino acids, both in vivo and in vitro, the radioactivity in protein $12 \mathrm{~s}$ decreases with time, whereas the radioactivity in protein 17-18s increases (Seed \& Goldberg, 1963, 1965; Nunez et al. 1967; Ekholm \& Strandberg, 1967a,b; Cavalieri \& Searle, 1967). The labelled protein $12 \mathrm{~s}$ is immunologically related to thyroglobulin (Sellin \& Goldberg, 1965). Radioactivity from both the $12 \mathrm{~s}$ and the 3-8s fractions can be transferred to protein $19 \mathrm{~s}$ by incubation with unlabelled thyroglobulin, presumably through an exchange of subunits (Goldberg \& Seed, 1965). These observations led to the conclusion that protein $12 \mathrm{~s}$ is a precursor of thyroglobulin analogous to a subunit with one-half of its molecular weight. The 3-8s fraction probably contains another precursor of thyroglobulin with one-quarter of its molecular weight and a sedimentation coefficient of $5 \mathrm{~s}$ (Vecchio et al. 1966).

The synthesis of the carbohydrate groups of thyroglobulin from $\left[{ }^{14} \mathrm{C}\right] g l u c o s e$ was studied by
Spiro \& Spiro (1966) in calf thyroid slices. They demonstrated that formation of the carbohydrate groups follows that of the peptide backbone of thyroglobulin, both components being assembled at a particulate site. In addition, they presented some evidence which suggested that the synthesis of the carbohydrate units precedes iodination via a stepwise attachment of monosaccharide residues.

It is not known at what stage in the elaboration of thyroglobulin from its subunit precursors addition of carbohydrate to the peptides occurs. In the present work this problem was investigated by comparing the incorporation of ${ }^{14} \mathrm{C}$-labelled galactose and mannose to that of $\left[{ }^{3} \mathrm{H}\right]$ leucine into non-iodinated thyroglobulin (protein 17-18s) and its presumed precursors (protein 12s and 3-8s). The evidence obtained supports the idea of a stepwise attachment of carbohydrate to thyroglobulin before its iodination. Mannose is incorporated on subunit precursors of thyroglobulin at about the same time as leucine, whereas galactose is added more than $30 \mathrm{~min}$. later, either on subunits immediately before their aggregation or directly on protein 17-18s.

\section{MATERIALS AND METHODS}

Animals. Adult Sherman rats (200-300g.) of both sexes bred in our laboratory and maintained on a diet of Purina chow were used.

Radioactive chemicals. All radioactive compounds were obtained from The Radiochemical Centre, Amersham, Bucks.

Other chemicals. Puromycin dihydrochloride and sodium pyruvate were purchased from Nutritional Biochemicals Corp., Cleveland, Ohio, U.S.A. Essentially glucose-free D-galactose was a product of Sigma Chemical Co., St Louis, Mo., U.S.A. Ion-exchange resins were analytical-grade products of Bio-Rad Laboratories, Richmond, Calif., U.S.A. All other chemicals were reagent grade.

Preparation of thyroids. Tracheas bearing thyroid glands were removed from rats maintained under ether anaesthesia, and placed in cold oxygenated saline ( $0 \cdot 15 \mathrm{M}$-sodium chloride in 0.01 M-phosphate buffer, $\mathrm{pH} 6 \cdot 8$ ). The thyroid lobes were detached from the tracheas and cleared of connective tissue while submerged in cold saline. Whole lobes were used for incubation.

Incubation. Whole thyroid lobes were incubated at $37^{\circ}$ in a shaking water bath in Krebs-Ringer bicarbonate solution containing $143 \mathrm{mM}-\mathrm{NaCl}, 5.6 \mathrm{mM}-\mathrm{KCl}, 1.42 \mathrm{mM}$ $\mathrm{KH}_{2} \mathrm{PO}_{4}, \quad 1.42 \mathrm{~mm}-\mathrm{MgSO}_{4}, \quad 3.0 \mathrm{~mm}-\mathrm{CaCl}_{2}$ and $25 \mathrm{~mm}$ $\mathrm{NaHCO}_{3}$ (Umbreit, Burris \& Stauffer, 1957). The solutions were gassed for 5-10 min. with $\mathrm{O}_{2}+\mathrm{CO}_{2}$ (95:5) before incubation. A preincubation of $15 \mathrm{~min}$. was usually carried out before the addition of radioactive precursors, since it was found greatly to enhance the incorporation of $\left[{ }^{14} \mathrm{C}\right]$ mannose and $\left[{ }^{14} \mathrm{C}\right]$ galactose.

Sucrose-gradient centrifugation of thyroid proteins. After incubation the flasks were cooled in crushed ice, the medium was discarded and the thyroid lobes were rinsed twice with $5 \mathrm{ml}$. of cold saline. Preparation of soluble thyroid proteins 
was performed as described by Seed \& Goldberg (1963). The thyroid lobes were homogenized in $2 \mathrm{ml}$. of saline and the homogenate was centrifuged in a Sorvall refrigerated centrifuge at $25000 \mathrm{~g}_{\max }$ for $20 \mathrm{~min}$. The proteins in the supernatant solution were precipitated three times in $\mathbf{7 0} \%$ saturated $\left(\mathrm{NH}_{4}\right)_{2} \mathrm{SO}_{4}$ soln., $\mathrm{pH} 6 \cdot 8$. The last precipitate was dissolved in $0.5 \mathrm{ml}$. of saline and dialysed overnight against saline at $4^{\circ}$. A portion of the dialysed protein solution was layered on top of a 5-20\% continuous sucrose gradient in saline. The procedure used for the preparation of gradients was essentially that described by Martin \& Ames (1961), except that the total volume of the gradients was $3.4 \mathrm{ml}$. Centrifugation was carried out at $4^{\circ}$ for $4 \mathrm{hr}$. at $55000 \mathrm{rev} . / \mathrm{min}$. in the SB 405 rotor of the International B60 ultracentrifuge. The results were similar to those obtained after centrifugation in rotor SW 39L of the Spinco model $\mathrm{L}$ at $39000 \mathrm{rev} . / \mathrm{min}$. for $8 \mathrm{hr}$. After centrifugation, the bottom of the tube was pierced and fractions were collected drop by drop. Water $(1 \mathrm{ml}$.) was added to each fraction and $E$ at $280 \mathrm{~m} \mu$ was determined. A measured portion of each fraction was assayed for radioactivity.
Hydrolysis of thyroid proteins. Protein fractions were first dialysed at $4^{\circ}$ against several changes of water for 24-48 hr. In some cases the proteins were freeze-dried and resuspended in water. A portion of these protein fractions was hydrolysed in $\mathrm{M}-\mathrm{H}_{2} \mathrm{SO}_{4}$ at $100^{\circ}$ for $6 \mathrm{hr}$. as described by Spiro \& Spiro $(1965 a)$. The hydrolysate was passed successively through columns of Dowex $50 \mathrm{~W}\left(\mathrm{H}^{+}\right.$form; X4; 200-400 mesh) and Dowex 1 (formate form; X8; 200400 mesh). Two fractions were obtained: one fraction, which contained the neutral sugars, was not adsorbed on either resin and was eluted with water, and the other fraction, which contained amino acids, small peptides and glucosamine (Spiro, 1966), was adsorbed on Dowex 50. The radioactivity adsorbed on Dowex 50 was eluted with aq. $2 \mathrm{M}-\mathrm{NH}_{3}$ soln. The water eluate and the aq. $\mathrm{NH}_{3}$ eluate were concentrated in vacuo at $40^{\circ}$ and their radioactivity was determined and related to the radioactivity in the total hydrolysate.

Chromatography of neutral sugars. In some cases, unlabelled D-galactose and D-mannose were added to the neutral sugar fraction and descending paper chromato-

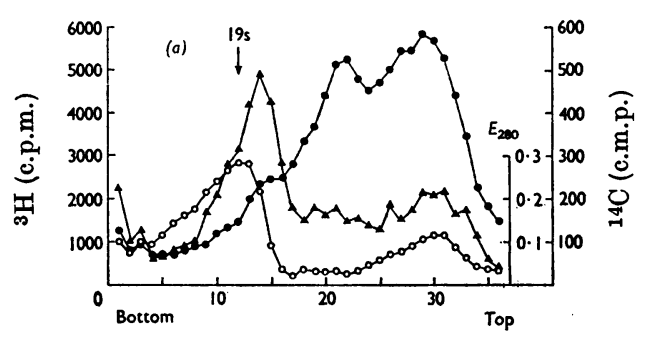

Fraction no.

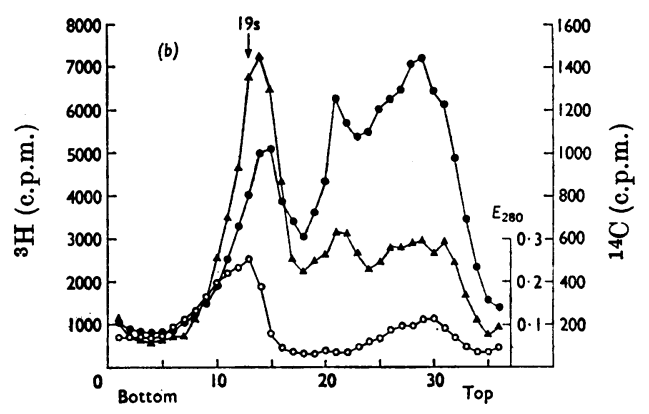

Fraction no.

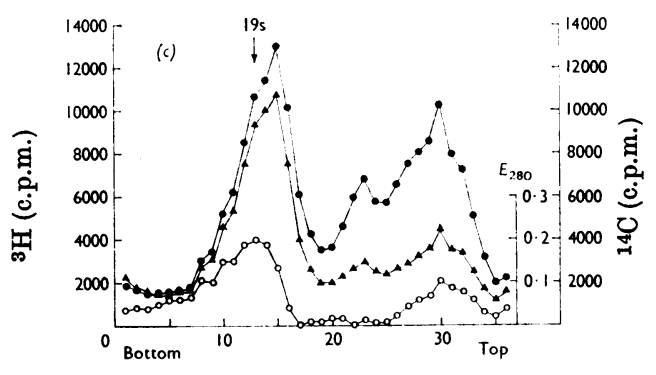

Fraction no.

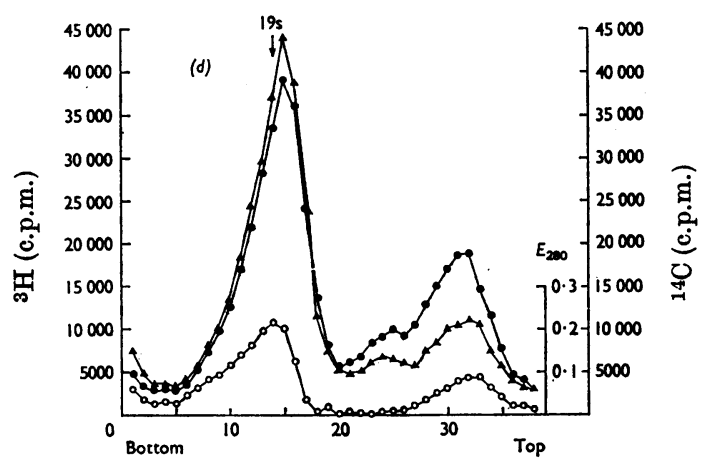

Fraction no.

Fig. 1. Gradient centrifugation of soluble proteins from thyroids double-labelled with $\left[{ }^{3} \mathrm{H}\right]$ leucine and $\left[{ }^{14} \mathrm{C}\right]-$ galactose in vitro. Whole thyroid lobes from 10 rats $\left(200-230 \mathrm{mg}\right.$. wet wt.) were incubated in each flask at $37^{\circ}$ in $2 \mathrm{ml}$. of Krebs-Ringer bicarbonate with a gas phase of $\mathrm{O}_{2}+\mathrm{CO}_{2}(95: 5)$. The lobes in $(a)$ and $(b)$ were hemithyroids obtained from the same animals, as were those in $(c)$ and $(d)$. For $(a)$ and $(b)$, the medium contained $10 \mu \mathrm{O}$ of $\mathrm{D}$-[1.14C]galactose (specific radioactivity $34.9 \mathrm{mc} / \mathrm{m}$-mole), and $100 \mu \mathrm{O}$ of $\mathrm{DL}-\left[4,5-{ }^{3} \mathrm{H}_{2}\right]$ leucine (specific radioactivity $23000 \mathrm{mc} / \mathrm{m}$-mole), and for $(c)$ and $(d), 50 \mu \mathrm{C}$ of $\mathrm{L}-\left[4,5-3 \mathrm{H}_{2}\right]$ leuoine, $1 \mu$ mole of unlabelled $\mathrm{L}$-leucine, and $10 \mu \mathrm{C}$ of $\mathrm{D}-[1.14 \mathrm{C}]$ galactose (specific radioactivity $35.4 \mathrm{mo} / \mathrm{m}-\mathrm{mole}$ ). Thyroids were incubated for: $(a) 30 \mathrm{~min}$; (b) $1 \mathrm{hr}$; (c) $2 \mathrm{hr}$; (d) $5 \mathrm{hr}$. Soluble thyroid proteins were separated by sucrose-gradient centrifugation. $E_{280}$ $(O)$, and ${ }^{14} \mathrm{C}(\Delta)$ and ${ }^{3} \mathrm{H}(\bullet)$ radioactivity, for each fraction were determined. The direction of sedimentation is from right to left. 
graphy on Whatman no. 1 paper was performed for $96 \mathrm{hr}$. in butan-1-ol-ethanol-water (10:1:2, by vol.) (Spiro \& Spiro, 1965a). Galactose and mannose were eluted in water from the chromatograms after staining guide strips with $p$-anisidine-HCl, and their radioactivity was determined. When known amounts of $\left[{ }^{14} \mathrm{C}\right]$ galactose and $\left[{ }^{14} \mathrm{C}\right]$ mannose were taken through the hydrolysis procedure, recovery of their radioactivity after paper chromatography was $\mathbf{8 0 \%}$ and $78 \%$ respectively.

Measurement of radioactivity in the acid-insoluble fraction. Rinsed thyroids were homogenized in $4 \mathrm{ml}$. of $6 \%$ trichloroacetic acid $-0.5 \%$ phosphotungstic acid, and allowed to stand in ice for $20 \mathrm{~min}$. The homogenate was centrifuged, the supernatant discarded and the precipitate washed three times with $2 \mathrm{ml}$. of cold $6 \%$ trichloroacetic acid- $0.5 \%$ phosphotungstic acid. Lipids were removed from the precipitate by two extractions with $5 \mathrm{ml}$. of chloroformmethanol-diethyl ether $(2: 1: 1$, by vol.) at room temperature (Lawford \& Schachter, 1966). The defatted residue was allowed to dry in air at room temperature, and then was dissolved in $1 \mathrm{ml}$. of $0.5 \mathrm{M}-\mathrm{NaOH}$ with heating at $90^{\circ}$ for $30 \mathrm{~min}$. Portions of this alkali digest were taken for radioactivity measurements and for protein determination by the method of Lowry, Rosebrough, Farr \& Randall (1951).

Measurement of radioactivity. Radioactivity was assayed in a three-channel Packard Tri-Carb liquid-scintillation spectrometer. The spectrometer was set either for simultaneous assay of ${ }^{14} \mathrm{C}$ and ${ }^{3} \mathrm{H}$, or for the estimation of ${ }^{14} \mathrm{C}$ alone. The scintillation mixture contained $100 \mathrm{~g}$. of naphthalene, $7 \mathrm{~g}$. of 2,5-diphenyloxazole and $300 \mathrm{mg}$. of 1,4-bis-(5-phenyloxazol-2-yl)benzene/l. of dioxan, except for the alkali digests. In this case, a mixture of $80 \mathrm{~g}$. of naphthalene, $5 \mathrm{~g}$. of 2,5-diphenyloxazole and $50 \mathrm{mg}$. of 1,4-bis-(4-methyl-5-phenyloxazol-2-yl)benzene/l. of toluene-dioxan-ethanol (1:1:1, by vol.) was used.

\section{RESULTS}

Thyroid lobes were incubated for various periods of time in medium containing both $\left[{ }^{3} \mathrm{H}\right]$ leucine and a ${ }^{14} \mathrm{C}$-labelled carbohydrate to allow direct comparison between the labelling of the peptide and carbohydrate components of thyroid glycoproteins. When soluble thyroid proteins are separated by sucrose-gradient centrifugation (Figs. 1, 2 and 4), the major peak of ultraviolet-absorbing material near the bottom of the gradient represents $19 \mathrm{~s}$ thyroglobulin and is used as a reference point on the gradients, whereas the other peak near the top of the gradient contains thyroid proteins contaminated with serum proteins (Salvatore, Salvatore, Cahnmann \& Robbins, 1964).

Incorporation of $\left[{ }^{3} \mathrm{H}\right]$ leucine. After $30 \mathrm{~min}$. of incubation, there was little radioactivity from $\left[{ }^{3} \mathrm{H}\right]$ leucine in the region of thyroglobulin, but radioactivity was observed in two lighter fractions with peaks at $12 \mathrm{~s}$ and 3-8s (Fig. $1 a, 2 a, 4)$. After 60 min. of incubation ${ }^{3} \mathrm{H}$ was present in the region of thyroglobulin with a peak at 17-18s, and after $2 \mathrm{hr}$. or longer the amount of radioactivity in fraction 17-18s exceeded that present in either the $12 \mathrm{~s}$ or the 3-8s fractions (Fig. $1 b-d$ ).

Incorporation of $\left[{ }^{14} \mathrm{C}\right]$ galactose. With $\left[{ }^{14} \mathrm{C}\right]$ galactose as precursor there was no apparent lag

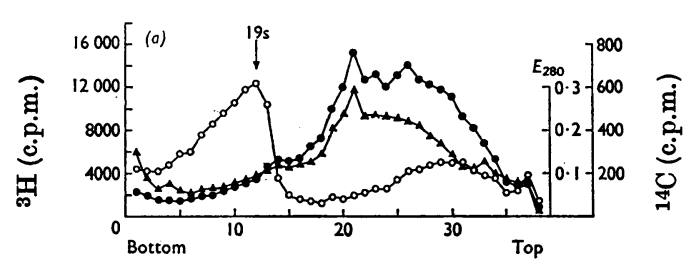

Fraction no.

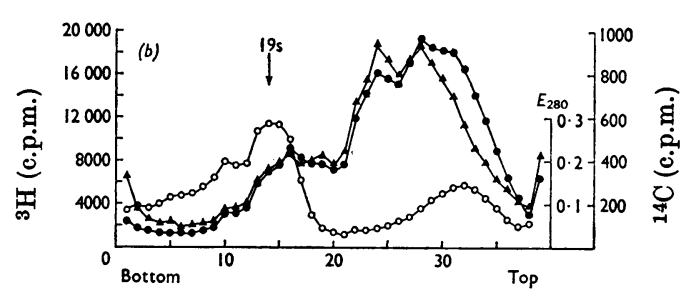

Fraction no.

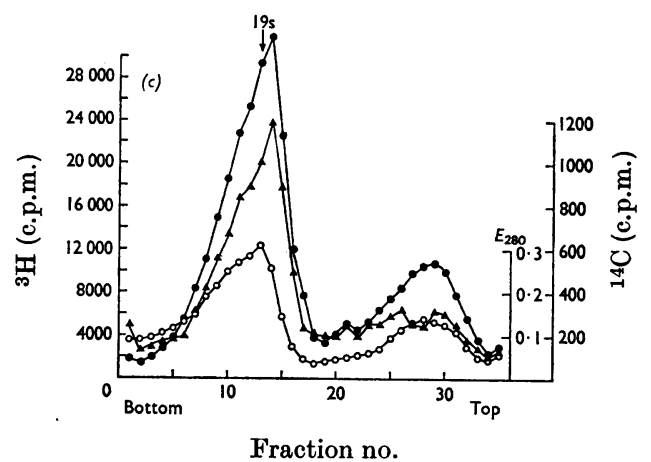

Fig. 2. Gradient-centrifugation of soluble proteins from thyroids pulse-labelled with $\left[{ }^{3} \mathrm{H}\right]$ leucine and $\left[{ }^{14} \mathrm{C}\right]$ mannose in vitro. Whole thyroid lobes from 40 rats (about $800 \mathrm{mg}$. wet wt.) were first incubated for $30 \mathrm{~min}$. at $37^{\circ}$ in $4 \mathrm{ml}$. of Krebs-Ringer bicarbonate containing $10 \mathrm{~mm}$-sodium pyruvate, $10 \mathrm{~mm}$-D-galactose, $40 \mu \mathrm{C}$ of $\mathrm{D}-[1-14 \mathrm{C}]$ mannose (specific radioactivity $27.5 \mathrm{mc} / \mathrm{m}$-mole) and $200 \mu \mathrm{C}$ of $\mathrm{L}-\left[4,5-{ }^{3} \mathrm{H}_{2}\right]$ leucine (specific radioactivity $29100 \mathrm{mc} / \mathrm{m}-\mathrm{mole}$ ). At the end of this pulse the medium was discarded, the thyroids were rinsed twice with $5 \mathrm{ml}$. of saline and divided into four groups. One group of thyroids (a) was analysed without 'chase'. The others were incubated at $37^{\circ}$ in $2 \mathrm{ml}$. of fresh Krebs-Ringer bicarbonate, containing $10 \mathrm{~mm}-\mathrm{L}$-leucine, $10 \mathrm{~mm}$-D-mannose, $10 \mathrm{~mm}$-D-galactose and $10 \mathrm{~mm}$-sodium pyruvate, for $20 \mathrm{~min}$. (b) and $2 \mathrm{hr}$. (c). At the end of the 'chase', soluble thyroid proteins were separated by sucrosegradient centrifugation. $E_{280}(O)$, and the ${ }^{14} \mathrm{C}(\Delta)$ and ${ }^{3} \mathrm{H}$ (৩) radioactivity, for each fraction were determined. The direction of sedimentation is from right to left. 
in the appearance of radioactivity in protein 1718s (Fig. 1a). At all times examined, from $10 \mathrm{~min}$. to $5 \mathrm{hr}$., there was always more ${ }^{14} \mathrm{C}$ present in protein $17-18 \mathrm{~s}$ than in either $12 \mathrm{~s}$ or $3-8 \mathrm{~s}$ fractions (Fig. 1).

After $30 \mathrm{~min}$. of incubation with [ $\left.{ }^{14} \mathrm{C}\right]$ galactose, $78 \%$ of the radioactivity in protein $17-18 \mathrm{~s}$ was present in galactose. On the other hand, only $33 \%$ of the radioactivity in the combined 3-12s fractions was recovered in galactose : most of the radioactivity was found in mannose and the aq. ammonia eluate (Table 1). These results indicate that the incorporation of galactose into the carbohydrate groups of protein 17-18s occurred rapidly without the lag observed for the incorporation of amino acids, and that little galactose was incorporated as such into the $12 \mathrm{~s}$ and $3-8 \mathrm{~s}$ fractions.

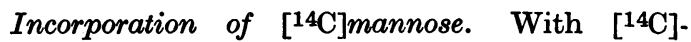
mannose as precursor, the $12 \mathrm{~s}$ and 3-8s fractions were labelled before a radioactive peak was observed in protein 17-18s (Fig. 2a). After a lag of at least $30 \mathrm{~min}$. a peak of ${ }^{14} \mathrm{C}$ radioactivity appeared in protein 17-18s. These observations agree with those reported by Lissitzky et al. (1965b).

When thyroids were pulse-labelled for $30 \mathrm{~min}$. in the presence of both $\left[{ }^{3} \mathrm{H}\right]$ leucine and $\left[{ }^{14} \mathrm{C}\right]$ mannose, and subsequently incubated for different periods of time in a 'chase' medium containing a large excess of unlabelled leucine and mannose, the incorporation of both labels into protein 17-18s increased continuously during the 'chase' (Fig. $2 b, c)$. This synthesis of protein 17-18s proceeded

Table 1. Distribution of radioactivity after hydrolysis of thyroid soluble proteins labelled in the presence of $\left.{ }^{14} \mathrm{C}\right]$ galactose in vitro

Thyroid lobes from 30 rats ( $490 \mathrm{mg}$. wet wt.) were incubated for $30 \mathrm{~min}$. in $4 \mathrm{ml}$. of Krebs-Ringer bicarbonate containing $60 \mu \mathrm{C}$ of $\mathrm{D}-\left[1-{ }^{14} \mathrm{C}\right]$ galactose (specific radioactivity, $34.9 \mathrm{mc} / \mathrm{m}$-mole). Soluble proteins were separated by sucrose-gradient centrifugation, and portions of the fractions thus obtained were assayed for ${ }^{14} \mathrm{C}$ radioactivity. The tubes containing the labelled fractions 17-18 s and 3-12 s were pooled, dialysed against water and freeze-dried. The freeze-dried proteins were hydrolysed, the hydrolysate was passed through ion-exchange resins, and the neutral sugar fraction chromatographed as described in the text. Of the radioactivity present in protein 17-18 s before hydrolysis $\mathbf{7 7 \%}$ was recovered in galactose, mannose and the aq. $\mathrm{NH}_{3}$ eluate. Similarly, $88 \%$ of the radioactivity in protein 3-12 $\mathrm{s}$ was recovered. The results are expressed as $\%$ of the recovered radioactivity for each protein fraction.

Protein

fraction

17-18s

3-12s
Recovered radioactivity (\%)

$\begin{array}{ccc}\text { Galactose } & \text { Mannose } & \begin{array}{c}\text { Aq. } \mathrm{NH}_{3} \\ \text { eluate }\end{array} \\ 78 & 13 & 9 \\ 33 & 40 & 27\end{array}$
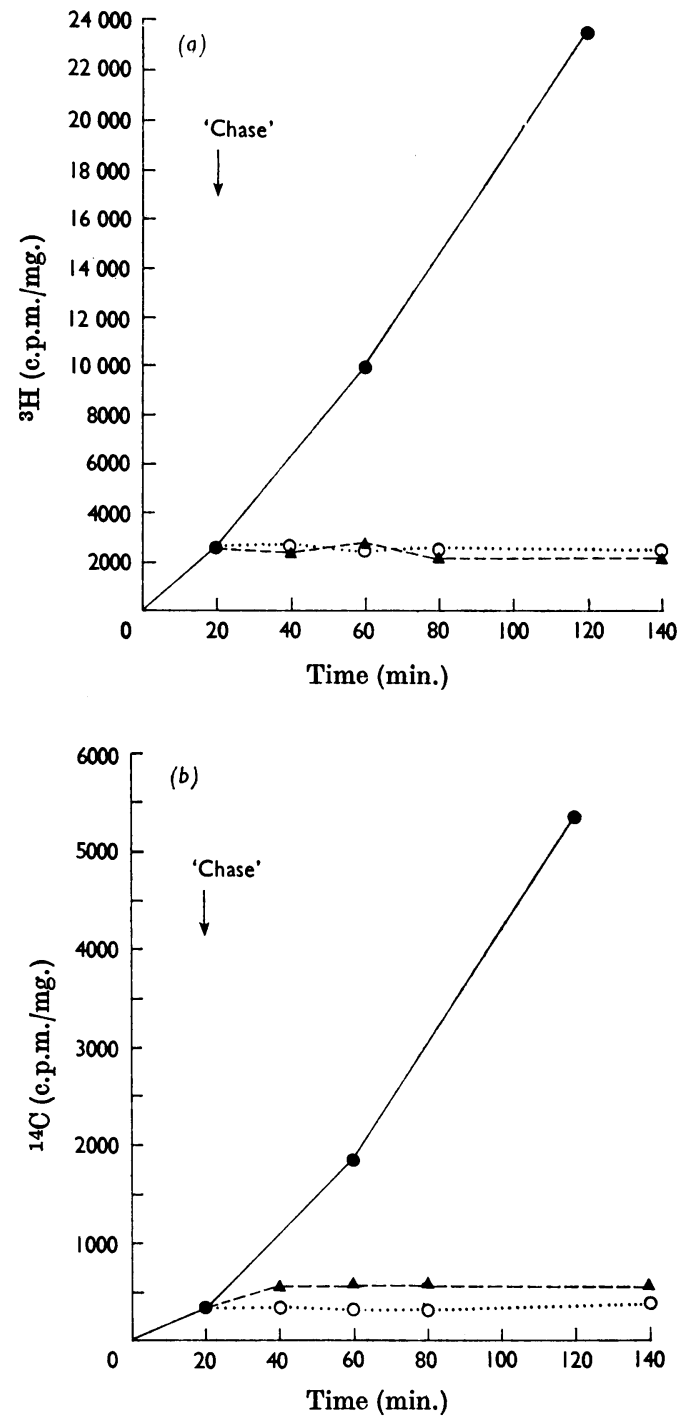

Fig. 3. Time-course of incorporation of radioactivity from $\left[{ }^{3} \mathrm{H}\right]$ leucine and $\left[{ }^{14} \mathrm{C}\right]$ mannose into the acid-insoluble fraction of rat thyroids in vitro. Whole thyroid lobes from four rats (about $80 \mathrm{mg}$. wet wt.) were incubated in each flask at $37^{\circ}$ in $2 \mathrm{ml}$. of Krebs-Ringer bicarbonate containing $5 \mu \mathrm{o}$ of D-[1-14 C]mannose (specific radioactivity $27 \cdot 5 \mathrm{mc} / \mathrm{m}-\mathrm{mole}$ ) and $10 \mu \mathrm{C}$ of $\mathrm{L}-\left[4,5-{ }^{3} \mathrm{H}_{2}\right]$ leucine (specific radioactivity $14700 \mathrm{mc} / \mathrm{m}-\mathrm{mole})$. Some thyroids were incubated continuously in this medium (-๑); others were incubated in this medium for only $20 \mathrm{~min}$., washed with saline and transferred to $2 \mathrm{ml}$. of fresh Krebs-Ringer bicarbonate containing 5 mM-D-mannose and 5 mM-L-leucine. This 'chase' incubation was then carried out for different periods of time with $(0 \cdots \cdots)$ or without $(\boldsymbol{\Delta}-\cdots-\boldsymbol{\Delta})$ puromycin dihydrochloride (125 $\mu \mathrm{g} . / \mathrm{ml}$.). The ${ }^{3} \mathrm{H}(a)$ and ${ }^{14} \mathrm{C}(b)$ radioactivity in the acid-insoluble fraction was determined as described in the text, and expressed as c.p.m./mg. of protein. 
Table 2. Distribution of radioactivity after hydrolysis of soluble thyroid proteins labelled with

$\left[{ }^{14} \mathrm{C}\right]$ mannose in vitro

Soluble protein fractions obtained by sucrose-gradient centrifugation were treated as described in Table 1 . In Expt. 1, the thyroid lobes (750 mg. wet wt.) were incubated for $60 \mathrm{~min}$. in $8 \mathrm{ml}$. of Krebs-Ringer bicarbonate containing $120 \mu \mathrm{C}$ of $\mathrm{D}-[1-14 \mathrm{C}]$ mannose (specific radioactivity, $25 \cdot 8 \mathrm{mc} / \mathrm{m}$-mole). In Expt. 2 , the lobes (800 mg. wet wt.) were incubated in $4 \mathrm{ml}$. of $\mathrm{Krebs}-$ Ringer bicarbonate containing $40 \mu \mathrm{c}$ of $\mathrm{D}-[1-14 \mathrm{C}]$ mannose (specific radioactivity, $27.5 \mathrm{mc} / \mathrm{m}$-mole), $10 \mathrm{~mm}$-sodium pyruvate and $10 \mathrm{~mm}-\mathrm{D}$-galactose, for $30 \mathrm{~min}$. Half the thyroids were rinsed and reincubated for a $60 \mathrm{~min}$. 'chase' period in Krebs-Ringer bicarbonate containing $10 \mathrm{~mm}$-sodium pyruvate, $10 \mathrm{mM}-\mathrm{D}$-galactose and $10 \mathrm{~mm}-\mathrm{D}$-mannose, and the other half were analysed without further incubation. Between 75 and $85 \%$ of the radioactivity present in each protein fraction before hydrolysis was recovered in galactose, mannose and the aq. $\mathrm{NH}_{3}$ eluate, except for protein 17-18s in Expt. 2, in which $66 \%$ of the radioactivity was recovered. The results are expressed as $\%$ of the recovered radioactivity for each protein fraction.

\begin{tabular}{|c|c|c|c|c|c|c|}
\hline \multirow[b]{2}{*}{ Expt. no. } & \multirow[b]{2}{*}{$\begin{array}{l}\text { Pulse } \\
\text { (min.) }\end{array}$} & \multirow[b]{2}{*}{$\begin{array}{l}\text { 'Chase' } \\
\text { (min.) }\end{array}$} & \multirow[b]{2}{*}{ Protein fraction } & \multicolumn{3}{|c|}{ Recovered radioactivity (\%) } \\
\hline & & & & Galactose & Mannose & $\begin{array}{c}\text { Aq. } \mathrm{NH}_{3} \\
\text { eluate }\end{array}$ \\
\hline 1 & $\begin{array}{l}60 \\
60 \\
60\end{array}$ & $\begin{array}{l}0 \\
0 \\
0\end{array}$ & $\begin{array}{l}17-18 \mathrm{~s} \\
12 \mathrm{~s} \\
3-8 \mathrm{~s}\end{array}$ & $\begin{array}{r}25 \\
10 \\
8\end{array}$ & $\begin{array}{l}45 \\
62 \\
46\end{array}$ & $\begin{array}{l}30 \\
28 \\
46\end{array}$ \\
\hline 2 & $\begin{array}{l}30 \\
\mathbf{3 0}\end{array}$ & $\begin{array}{r}0 \\
60\end{array}$ & $\begin{array}{l}3-12 \mathrm{~s} \\
17-18 \mathrm{~s}\end{array}$ & $\begin{array}{l}3 \\
7\end{array}$ & $\begin{array}{l}74 \\
64\end{array}$ & $\begin{array}{l}23 \\
29\end{array}$ \\
\hline
\end{tabular}

Table 3. Effect of pyruvate and amino acids on the distribution of radioactivity after hydrolysis of soluble thyroid proteins labelled in the presence of $\left[{ }^{14} \mathrm{C}\right]$ mannose in vitro

Rat thyroid lobes (100-150 mg. wet wt.) were incubated for $1 \mathrm{hr}$. in $2 \mathrm{ml}$. of $\mathrm{Krebs}-$ Ringer bicarbonate containing $20 \mu \mathrm{C}$ of [1.14 $\mathrm{C}]$ mannose (specific radioactivity $31 \cdot 2 \mathrm{mc} / \mathrm{m}-\mathrm{mole}$ ). Before the incubation, a preincubation of $15 \mathrm{~min}$. was carried out with, or without, amino acids or sodium pyruvate at the concentrations indicated. The amino acid mixture contained (each $10 \mathrm{mM}$ ) glycine, L-alanine, L-serine, L-glutamine, L-aspartic acid and L-glutamic acid. The soluble proteins precipitated by $70 \%$ saturated $\left(\mathrm{NH}_{4}\right)_{2} \mathrm{SO}_{4}$ were hydrolysed as described in the text, and the radioactivity in the water eluate and the aq. $\mathrm{NH}_{3}$ eluate was determined. The water eluate contains neutral sugars and the aq. $\mathrm{NH}_{3}$ eluate contains components of the hydrolysate initially adsorbed on Dowex 50, including amino acids.

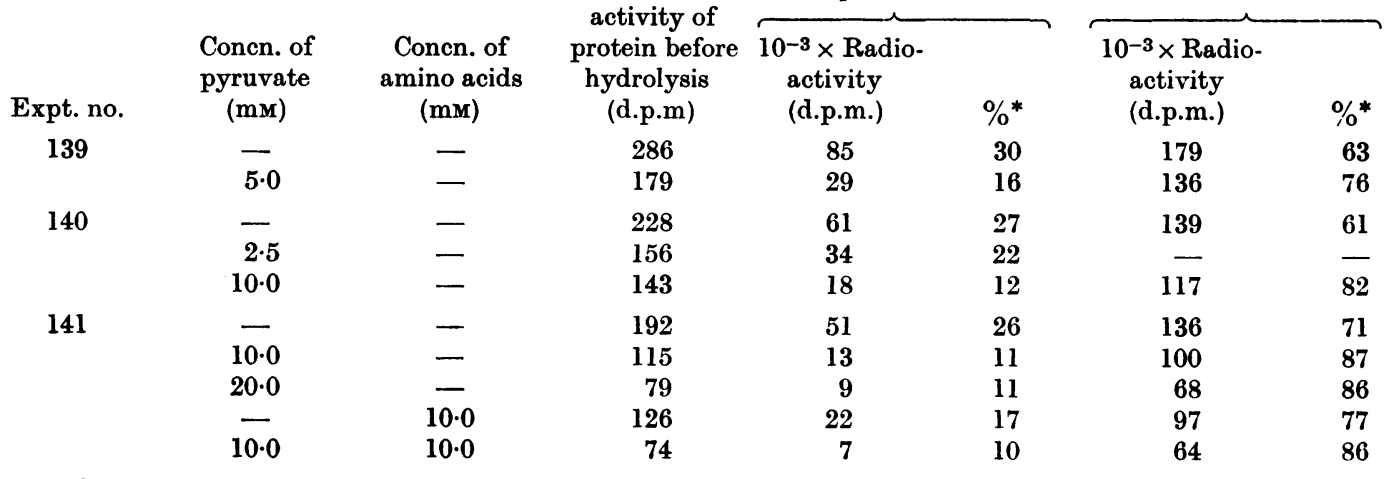

* $\%$ of the radioactivity present in each protein solution before hydrolysis.

at the expense of preformed labelled polypeptides, since on transfer of the lobes to fresh medium the labelling of total thyroid proteins in the acidinsoluble fraction ceased immediately for ${ }^{3} \mathbf{H}$ (Fig. 3a), and within $20 \mathrm{~min}$. for ${ }^{14} \mathrm{C}$ (Fig. $3 b$ ).

During the first $20 \mathrm{~min}$. of 'chase' there was an increase in radioactivity in the $12 \mathrm{~s}$ and $3-8 \mathrm{~s}$ protein fractions (Fig. 2b). Since the 'chase' was immediately effective in stopping further protein labelling with ${ }^{3} \mathrm{H}$ (Fig. $3 a$ ), the increase in labelling of $12 \mathrm{~s}$ and $3-8 \mathrm{~s}$ proteins was due to utilization of prelabelled proteins not extractable by homogenization in saline. The increase in labelling of protein 3-8s observed for ${ }^{14} \mathrm{C}$ was greater than that 


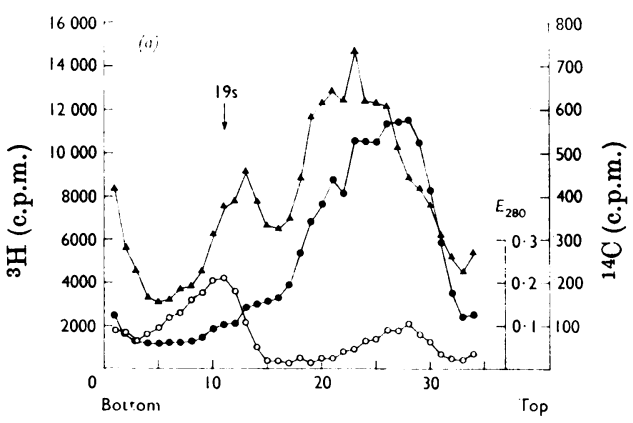

Fraction no.

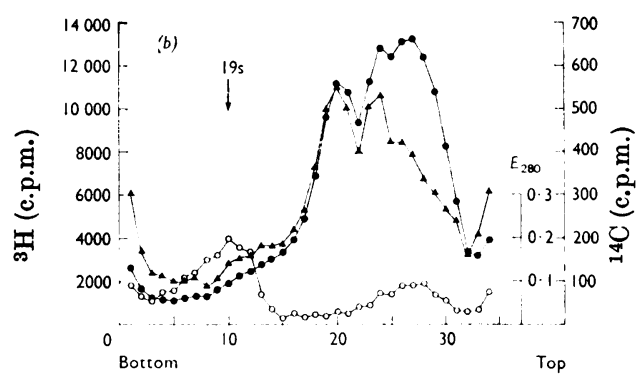

Fraction no.

Fig. 4. Effect of galactose on the incorporation of radioactivity from $\left[{ }^{14} \mathrm{C}\right]$ mannose and $\left[{ }^{3} \mathrm{H}\right]$ leucine into soluble thyroid proteins. Whole thyroid lobes from 10 rats $(180 \mathrm{mg}$. wet wt. in each flask) were incubated at $37^{\circ}$ in $2 \mathrm{ml}$. of Krebs-Ringer bicarbonate with a gas phase of $\mathrm{O}_{2}+\mathrm{CO}_{2}$ $(95: 5)$. The lobes in $(a)$ and $(b)$ were hemithyroids obtained from the same animals. The incubation period was $30 \mathrm{~min}$. The medium contained $100 \mu \mathrm{C}$ of $\mathrm{L}-\left[4,5 \cdot{ }^{3} \mathrm{H}_{2}\right]$ leucine (specific radioactivity $14700 \mathrm{mc} / \mathrm{m}$-mole), $20 \mu \mathrm{C}$ of $\mathrm{D}-\left[1-{ }^{14} \mathrm{C}\right]$ mannose (specific radioactivity $27.5 \mathrm{mc} / \mathrm{m}$-mole) and $10 \mathrm{~mm}$-sodium pyruvate. D-Galactose $(10 \mathrm{~mm})$ was either present $(b)$ or absent $(a)$. Soluble thyroid proteins were separated by sucrose-gradient centrifugation. $E_{280}(O)$, and the ${ }^{14} \mathrm{C}(\Delta)$ and ${ }^{3} \mathrm{H}(\bullet)$ radioactivity, in each fraction was determined. The direction of sedimentation is from right to left.

observed for ${ }^{3} \mathrm{H}$ because, in this case, the 'chase' was not immediately effective in the absence of puromycin (Fig. 3b). With longer 'chase' periods the double-labelled $12 \mathrm{~s}$ peak disappeared, and the amount of both labels in the 3-8s protein fraction was greatly reduced (Fig. 2c).

In the experiment depicted in Fig. 2, the KrebsRinger bicarbonate medium was supplemented with $10 \mathrm{~mm}$-sodium pyruvate and $10 \mathrm{~mm}$-galactose. Under these conditions, a large proportion of the radioactivity from $\left[{ }^{14} \mathrm{C}\right]$ mannose in the various protein fractions was recovered in mannose (64$74 \%$ ), and only a small proportion was found in the aq. ammonia eluate $(23-29 \%)$ and in galactose (3-7\%) (Table 2, Expt. no. 2).

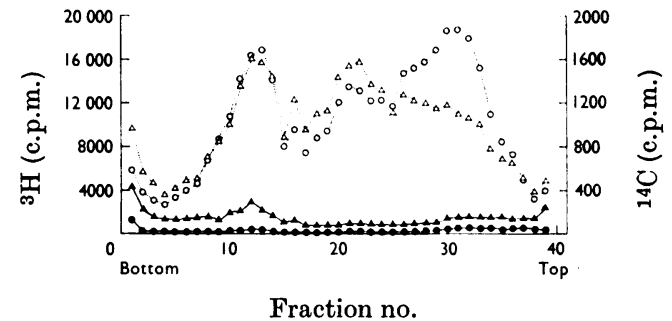

Fig. 5. Effect of puromycin on the incorporation of radioactivity from $\left[{ }^{14} \mathrm{C}\right]$ mannose and $\left[{ }^{3} \mathrm{H}\right]$ leucine into thyroid soluble proteins. Thyroid lobes from 10 rats $(180-186 \mathrm{mg}$. wet wt.) in each flask were incubated for $1 \mathrm{hr}$. at $37^{\circ}$ in $2 \mathrm{ml}$. of Krebs-Ringer bicarbonate with a gas phase of $\mathrm{O}_{2}+\mathrm{CO}_{2}$ (95:5). A preincubation of $15 \mathrm{~min}$. with (-) or without $(\cdots)$ puromycin dihydrochloride $(125 \mu \mathrm{g} . / \mathrm{ml}$.) was carried out before the addition of $100 \mu \mathrm{C}$ of $\mathrm{L}-\left[4,5-{ }^{3} \mathrm{H}_{2}\right]$ leucine (specific radioactivity $35100 \mathrm{mc} / \mathrm{m}-\mathrm{mole}$ ) and $10 \mu \mathrm{C}$ of $\mathrm{D}-\left[1-{ }^{14} \mathrm{C}\right]$ mannose (specific radioactivity $24.3 \mathrm{mc}$ / $\mathrm{m}$-mole). The lobes in control and puromycin-containing flasks were hemithyroids obtained from the same animals. At the end of the incubation, soluble thyroid proteins were separated by sucrose-gradient centrifugation. ${ }^{14} \mathrm{C}(\Delta, \Delta)$ and ${ }^{3} \mathrm{H}(\bullet, 0)$ radioactivity was determined in each fraction. $\boldsymbol{E}_{280}$ is omitted from the graph, but identical profiles were obtained for control and puromycin-treated thyroid glands. The amount of protein placed on each gradient is about two-thirds of the amount on each gradient in Fig. 2. The direction of sedimentation is from right to left.

Effect of pyruvate on incorporation of [14C]mannose. The addition of pyruvate decreased the amount of radioactivity incorporated into the total soluble proteins from [ $\left.{ }^{14} \mathrm{C}\right]$ mannose (Table 3). After hydrolysis of these proteins, it was found that pyruvate inhibited the incorporation of ${ }^{14} \mathrm{C}$ into the aq. ammonia eluate containing amino acids far more than the incorporation into the water eluate containing neutral sugars. As a result, a much smaller proportion of the radioactivity in proteins was due to labelling of the peptide components in the presence of pyruvate than observed in control, the optimum effect being obtained at a concentration of $10 \mathrm{~mm}$. This effect was probably due to dilution of the specific radio-activity of amino acids formed from [ ${ }^{14} \mathrm{C}$ ] mannose by amino acids formed from the added pyruvate. This interpretation is supported by the fact that addition of a mixture of amino acids also decreased the proportion of radioactivity recovered in the aq. ammonia eluate, although not as effectively as pyruvate at the same concentration (Table 3).

Effect of galactose on incorporation of $\left[{ }^{14} \mathrm{C}\right]$ mannose. It was observed that a small amount of conversion of [ $\left.{ }^{14} \mathrm{C}\right]$ mannose into galactose occurred, which was most significant in the 17-18s protein fraction (Table 2, Expt. no. 1), and which resulted 


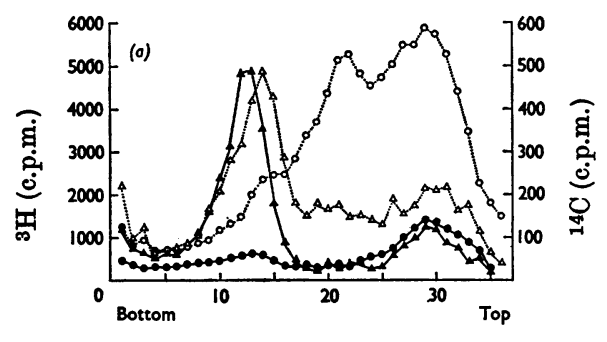

Fraction no.

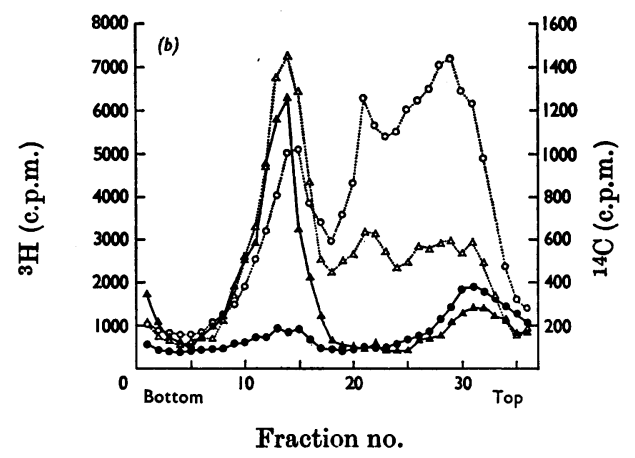

Fraction no.

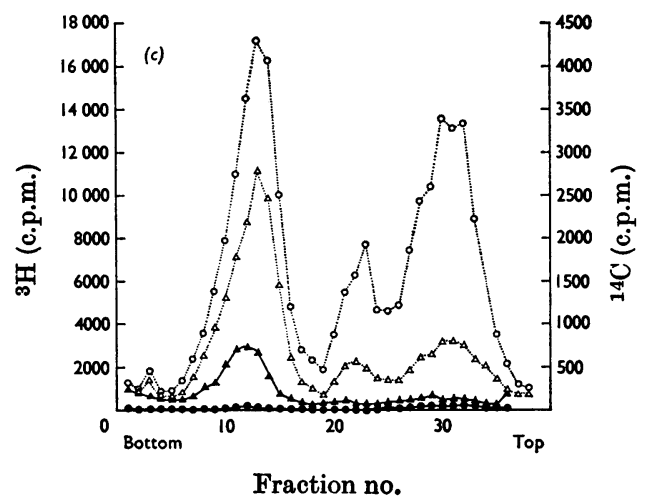

Fig. 6. Effect of puromycin on the incorporation of radioactivity from $\left[{ }^{14} \mathrm{C}\right]$ galactose and [ $\left.{ }^{3} \mathrm{H}\right]$ leucine into thyroid soluble proteins. Whole thyroid lobes were incubated at $37^{\circ}$ in $2 \mathrm{ml}$. of $\mathrm{Krebs-Ringer} \mathrm{bicarbonate} \mathrm{with}$ a gas phase of $\mathrm{O}_{2}+\mathrm{CO}_{2}(95: 5)$. A preincubation of $15 \mathrm{~min}$. with $(-)$ or without $(\cdots)$ puromycin dihydrochloride $(125 \mu \mathrm{g} . / \mathrm{ml}$.) was first carried out before the addition of radioactive precursors. The lobes in the control and puromycin-treated samples were hemithyroids obtained from the same rats. For $(a)$ and $(b)$, lobes from 10 rats $(200-230 \mathrm{mg}$. wet wt.) were present in each flask and the radioactive precursors were $100 \mu \mathrm{c}$ of $\mathrm{DL}-\left[4,5-{ }^{3} \mathrm{H}_{2}\right]$ leucine (specific radioactivity $23000 \mathrm{mo} / \mathrm{m}-\mathrm{mole}$ ) and $10 \mu \mathrm{O}$ of $\mathrm{D}-\left[1 .{ }^{14} \mathrm{C}\right]$ galactose (specific radioactivity 34.9 mc/m-mole). For (c), lobes from five rats (about $95 \mathrm{mg}$. wet wt.) were present in each flask containing $50 \mu \mathrm{O}$ of $\mathrm{L}-\left[4,5-{ }^{3} \mathrm{H}_{2}\right]$ leucine (specific radioactivity $23500 \mathrm{mc} / \mathrm{m}$-mole) and $10 \mu \mathrm{C}$ of $\mathrm{D}$-[1-14 $\left.\mathrm{C}\right] \mathrm{galactose}$ (specific radioactivity $34.9 \mathrm{mc} / \mathrm{m}$-mole). Thyroids were incubated for: $(a) 30 \mathrm{~min} . ;(b) 1 \mathrm{hr} . ;(c) 2 \mathrm{hr},{ }^{14} \mathrm{C}(\Delta, \Delta)$ and ${ }^{3} \mathrm{H}(\bullet, 0)$ radioactivity of fractions after sucrose-gradient centrifugation of control and puromycin-treated thyroid proteins were plotted on the same graph. In $(a)$ and $(c)$ the 17-18 s peaks in control and puromycintreated material do not coincide because the control gradients have extra tubes. The direction of sedimentation is from right to left. $E_{280}$ is omitted from the graph, but the profiles obtained for both puromycin-treated thyroid glands and for control were identical. For $(a)$ and $(b)$ these profiles are shown in Fig. 1(a) and $1(b)$ respectively. For $(c)$ the amount of protein on each gradient was about half that used for $(a)$ and $(b)$.

in the early appearance of ${ }^{14} \mathrm{C}$ in protein $17-18 \mathrm{~s}$ (Fig. 4a). The addition of $10 \mathrm{~mm}$-galactose to the medium decreased this conversion (Table 2, Expt. no. 2) and prevented the premature appearance of ${ }^{14} \mathrm{C}$ in protein 17-18 $\mathrm{s}$ with little effect on the labelling of 12s and 3-8s protein fractions (Fig. 4b).

Effect of puromycin. Puromycin at a concentration of $0.25 \mathrm{~mm}$ greatly inhibited the incorporation of radioactivity from $\left[{ }^{3} \mathrm{H}\right]$ leucine into all protein fractions within $30 \mathrm{~min}$. of incubation (Figs. 5 and 6).

Similarly, puromycin inhibited the incorporation of radioactivity from $\left[{ }^{14} \mathrm{C}\right]$ mannose into all soluble proteins to nearly the same extent as that from $\left[{ }^{3} \mathrm{H}\right]$ leucine (Fig. 5). This observation was made both in the presence and in the absence of pyruvate.

In contrast, puromycin had no effect on the incorporation of radioactivity from $\left[{ }^{14} \mathrm{C}\right]$ galactose into protein 17-18s during the initial $30 \mathrm{~min}$. of incubation (Fig. 6a). It inhibited this incorporation slightly after $1 \mathrm{hr}$. of incubation (Fig. $6 b$ ), and very markedly after $2 \mathrm{hr}$. (Fig. 6c). At all times examined, puromycin greatly inhibited the incorporation of radioactivity from $\left[{ }^{14} \mathrm{C}\right]$ galactose into $12 \mathrm{~s}$ and 3-8s protein fractions, an effect due mostly to the large proportion of labelled mannose and amino acids in these fractions (see Table 1). It appears 


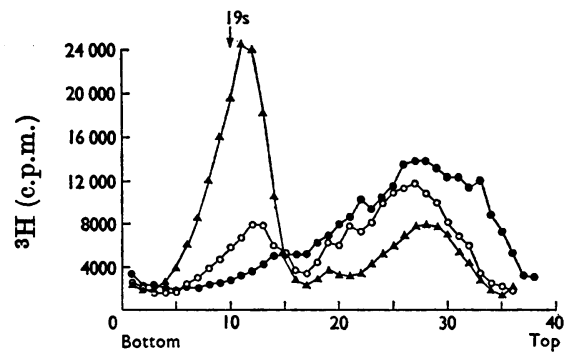

Fraction no.

Fig. 7. Effect of puromycin on the synthesis of protein 17-18 s from ${ }^{3} \mathrm{H}$-labelled protein precursors. Rat thyroid lobes from 30 rats (about $600 \mathrm{mg}$. wet wt.) were pulselabelled at $37^{\circ}$ for $30 \mathrm{~min}$. in $4 \mathrm{ml}$. of Krebs-Ringer bicarbonate containing $200 \mu \mathrm{C}$ of $\mathrm{L}-\left[4,5-{ }^{3} \mathrm{H}_{2}\right]$ leucine (specific radioactivity $14700 \mathrm{mc} / \mathrm{m}$-mole). At the end of this incubation the thyroids were divided into three groups. One group was analysed without further incubation (0). The other two groups were incubated for $2 \mathrm{hr}$. in $2 \mathrm{ml}$. of KrebsRinger bicarbonate containing $10 \mathrm{~mm}-\mathrm{L}$-leucine with (O) or without (A) puromycin dihydrochloride $(125 \mu \mathrm{g} . / \mathrm{ml}$.). Soluble thyroid proteins were separated by sucrose-gradient centrifugation and the ${ }^{3} \mathrm{H}$ radioactivity in each fraction was determined. $E_{280}$ profiles were identical for the three groups of thyroids. The amount of protein placed on each gradient was similar to that used for gradients of Fig. 2. The direction of sedimentation is from right to left.

therefore that, whereas the incorporation of radioactivity from $\left[{ }^{3} \mathrm{H}\right]$ leucine and $\left[{ }^{14} \mathrm{C}\right]$ mannose into protein 17-18s was immediately inhibited by puromycin, the incorporation of radioactivity from $\left.{ }^{14} \mathrm{C}\right]$ galactose proceeded for nearly $1 \mathrm{hr}$. in the presence of puromycin.

In pulse-labelling 'chase' experiments with $\left[{ }^{3} \mathrm{H}\right]$ leucine, the addition of puromycin during the 'chase' almost completely prevented both the increase in labelling of protein 17-18s and the concomitant decrease in labelling of $3-8 \mathrm{~s}$ and $12 \mathrm{~s}$ protein fractions observed in the control (Fig. 7). The presence of puromycin during the 'chase' had no effect on the ${ }^{3} \mathrm{H}$ specific radioactivity of the total proteins in the acid-insoluble fraction (Fig. 3a). These results therefore indicate that, in rat thyroids, puromycin prevented the utilization of prelabelled precursor proteins for the formation of protein 17-18s.

\section{DISCUSSION}

The evidence reviewed in the introduction indicates that the synthesis of thyroglobulin occurs in various stages. First, subunits of thyroglobulin (12s and probably a component of the 3-8s fraction) are formed; at least $20 \mathrm{~min}$. later these sub-units are converted into a non-iodinated form of thyroglobulin (protein 17-18 s), which in turn becomes iodinated to $19 \mathrm{~s}$ thyroglobulin. In the present work it is demonstrated that ${ }^{14} \mathrm{C}$-labelled mannose and galactose are utilized for the synthesis of the carbohydrate groups of non-iodinated thyroglobulin (protein 17-18 s) by rat thyroids in vitro, and that mannose and galactose are incorporated at different times in the elaboration of this glycoprotein.

The time-course of incorporation of $\left[{ }^{14} \mathrm{C}\right]$ mannose into protein 17-18s closely parallels that observed for labelled amino acids (Fig. 2). This similarity is observed under conditions in which labelling of the peptide components from $\left[{ }^{14} \mathrm{C}\right]$ mannose is kept to a minimum. This requirement is met by the addition of pyruvate to the incubation medium (Table 3). As observed with $\left[{ }^{3} \mathrm{H}\right]$ leucine, radioactivity from $\left[{ }^{14} \mathrm{C}\right]$ mannose appears in protein $17-18 \mathrm{~s}$ only after a lag period of at least $30 \mathrm{~min}$., during which time the $12 \mathrm{~s}$ and $3-8 \mathrm{~s}$ protein fractions are labelled. When thyroids pulselabelled with both precursors are subsequently incubated in a "chase' medium, both the ${ }^{14} \mathrm{C}$ and ${ }^{3} \mathrm{H}$ peaks at $12 \mathrm{~s}$ disappear, and the amount of both isotopes in the 3-8 $\mathrm{s}$ fraction decreases considerably, and the labelling in protein 17-18s increases (Fig. 2). These results agree with those obtained by Seed \& Goldberg (1965) with labelled amino acids in sheep thyroid slices, and support the idea that the double-labelled 12s protein fraction and a part of the double-labelled 3-8s protein fraction are transformed into protein 17-18s. It can be concluded therefore that mannose is incorporated on subunits of thyroglobulin at about the same time as leucine. Since no labelling of thyroid polysomes in the presence of $\left[{ }^{14} \mathrm{C}\right]$ mannose has been observed (Bouchilloux \& Cheftel, 1966; Cartouzou, Greif, Depieds \& Lissitzky, 1967), it is likely that mannose is added to the polypeptide chains immediately after their release from the ribosomes.

In contrast, the appearance of labelled galactose in protein 17-18s occurs immediately (Fig. 1), indicating that galactose incorporation into the carbohydrate groups of thyroglobulin takes place at least $30 \mathrm{~min}$. later than that of mannose. This difference in time between the addition of the two sugars can be correlated with their relative positions in the oligosaccharides of thyroglobulin. It has been demonstrated that mannose is located closer than galactose to the polypeptide backbone of thyroglobulin (Spiro \& Spiro, 1965b). The present results therefore provide evidence for the concept that carbohydrate groups of thyroglobulin are formed in a stepwise manner (Spiro \& Spiro, 1966). Two enzymes, CMP-sialic acid transferase and UDP-galactose transferase, which probably take part in these processes, have been described in the thyroid (Spiro \& Spiro, 1967).

From the present results it cannot be established conclusively whether galactose is added to the 
carbohydrate groups before or after aggregation of subunits to protein $17-18 \mathrm{~s}$, as there is always a small amount of labelled galactose present in $12 \mathrm{~s}$ and 3-8s protein fractions (Table 1). Assuming that the $\left[{ }^{14} \mathrm{C}\right]$ galactose found in these fractions is not due to contamination, nor to breakdown of a labile form of protein 17-18s, there are two possible interpretations of the results. First, galactose may be incorporated exclusively on subunits immediately before their aggregation, with little accumulation of galactose-containing subunits at any time. If this interpretation were correct, it would imply that galactose addition, and possibly completion of the oligosaccharides, is a prerequisite for subunit aggregation. In this case it would suggest a role of carbohydrate in maintaining the structure of thyroglobulin. Secondly, there may be two stages at which galactose is incorporated: most of the galactose might be added directly on protein $17-18 \mathrm{~s}$, but a small part of the galactose might be incorporated on subunits at about the same time as mannose. This possibility would depend on heterogeneity in the structure of the oligosaccharides. Further work is required to establish the nature of the immediate galactose acceptor.

It was shown previously that the peak of newly iodinated thyroglobulin labelled with radioactive iodine sediments at $18-18.5 \mathrm{~s}$ in sucrose gradients, i.e. slightly faster than the peak of non-iodinated protein 17-18s (Goldberg \& Seed, 1965; Nunez et al. 1965). Since the peak of radioactivity from both $\left[{ }^{14} \mathrm{C}\right]$ galactose and $\left[{ }^{14} \mathrm{C}\right]$ mannose observed in the thyroglobulin region always coincides exactly with the peak of radioactivity from $\left[{ }^{3} \mathrm{H}\right]$ leucine at $17-18 \mathrm{~s}$, it is concluded that most, if not all, of the carbohydrate is added to thyroglobulin before it becomes iodinated. Further, galactose and mannose incorporation are independent of thyroglobulin iodination, since $1 \mathrm{~mm}$-propylthiouracil, which prevents iodination (Seed \& Goldberg, 1965; Nunez et al. 1965), has no effect on their incorporation into protein 17-18s (A. Herscovics, unpublished work).

Puromycin greatly inhibits mannose incorporation, but has little effect on galactose incorporation into protein 17-18s during the first hour of incubation (Figs. 5 and 6). These observations are similar to those of Spiro \& Spiro (1966), who observed less inhibition by puromycin of galactose labelling than of mannose labelling from $\left[{ }^{14} \mathrm{C}\right]$ glucose in the particulate fraction of calf thyroid slices. These results show that mannose incorporation into the carbohydrate groups of thyroglobulin depends on continued polypeptide-chain synthesis, whereas galactose incorporation is independent of it for nearly $1 \mathrm{hr}$. This difference suggests that there is a large pool of thyroglobulin precursors with incomplete carbohydrate, which can act as galactose acceptor, but only a very small pool, if any, that can act as mannose acceptor. It is also possible that puromycin affects enzymes required for mannose utilization to a greater extent than those required for galactose incorporation; or that the latter enzymes have a slower turnover than the former.

Puromycin almost completely prevents the utilization of labelled sub-unit precursors for the synthesis of protein 17-18s (Fig. 7). This observation differs from that of Seed \& Goldberg (1965) for sheep thyroid slices. They observed a small decrease in protein $12 \mathrm{~s}$ utilization, but the extent of synthesis of protein 17-18s from prelabelled polypeptide precursors was little affected by puromycin. The present results indicate that, at least in rat thyroid in vitro, utilization of prelabelled polypeptide precursors for thyroglobulin synthesis depends on continued polypeptide-chain synthesis. Recent work with guinea-pig thyroid indicates that $19 \mathrm{~s}$ thyroglobulin is composed of two different $12 \mathrm{~s}$ subunits, one of which accumulates in the gland (Salvatore, Aloj, Salvatore \& Edelhoch, 1967). These authors suggest that in some species these two types of $12 \mathrm{~s}$ subunits may be formed at different rates so that formation of one type may be the rate-limiting step in thyroglobulin synthesis. If this were the case in rat thyroid, it would explain the inhibitory effect of puromycin on the formation of protein 17-18s from prelabelled subunit precursors. The utilization of the prelabelled protein $12 \mathrm{~s}$ found in the supernatant fraction would depend on the simultaneous synthesis of another type of protein $12 \mathrm{~s}$, and would therefore be prevented by blocking polypeptide-chain synthesis.

Spiro \& Spiro (1966) have demonstrated that the synthesis of both the peptide and carbohydrate components of thyroglobulin in calf thyroid slices takes place at a particulate site. The present results do not contradict these findings, since it is likely that the soluble fraction examined contains proteins easily extracted from fragile subcellular particles as well as those originally present in the cell sap and in the colloid. Homogenization in saline can release proteins from thyroid microsomal fractions (Ekholm \& Strandberg, 1967a,b). Preliminary experiments indicate that the pellets obtained after centrifugation of homogenates contain labelled 17-18s and 12s protein components that can be extracted with digitonin, and which may be precursors of the supernatant proteins (A. Herscovics, unpublished work).

Radioautographic studies of thyroids after injection of labelled amino acid have indicated that the polypeptide components of thyroglobulin synthesized on the ribosomes first migrate to the cisternae of the rough endoplasmic reticulum, then to the Golgi apparatus, and finally into apical vesicles whence they are released into the thyroid 
colloid (Nadler, Young, Leblond \& Mitmaker, 1964). From these observations and the present results it seems likely that, in the course of migration of the incomplete glycoprotein through the various cell compartments, the addition of mannose occurs toward the beginning of the migration, probably in the rough endoplasmic reticulum, whereas galactose addition occurs at a later stage of migration, perhaps in the Golgi apparatus.

The author expresses appreciation to Dr C. P. Leblond, Dr R. M. Johnstone and Dr N. J. Nadler for their help in the preparation of this manuscript. The technical assistance of Miss C. Walker and Mrs L. Sheils is gratefully acknowledged. This work was supported by U.S. Public Health Service Grant no. 5T01 GM00721-07.

\section{REFERENCES}

Bouchilloux, S. \& Cheftel, C. (1966). Biochem. biophys. Res. Commun. 23, 305.

Cartouzou, G., Greif, R., Depieds, R. \& Lissitzky, S. (1967). Biochim. biophys. Acta, 138, 80.

Cavalieri, R. R. \& Searle, G. L. (1967). Biochem.J. 102, 25 c. Cheftel, C., Bouchilloux, S. \& Lissitzky, S. (1964). C. $R$. Acad. Sci., Paris, 259, 1458.

De Crombrugghe, B., Pitt-Rivers, R. \& Edelhoch, H. (1966). J. biol. Chem. 241, 2766.

Edelhoch, H. (1960). J. biol. Chem. 235, 1326.

Edelhoch, H. (1965). Recent Progr. Hormone Res. 21, 1.

Edelhoch, H. \& Lippoldt, R. E. (1960). J. biol. Chem. 235, 1335.

Ekholm, R. \& Strandberg, U. (1967a). J. Ultrastruct. Res. $17,184$.

Ekholm, R. \& Strandberg, U. (1967b). J. Ultrastruct. Res. $20,103$.

Goldberg, I. H. \& Seed, R. W. (1965). Biochem. biophys. Res. Commun. 19, 615.

Gottschalk, A. \& Ada, G. L. (1956). Biochem. J. 62, 681.

Lacombe, G. \& Michel, R. (1955). C. R. Soc. biol., Paris, $149,888$.

Lawford, G. R. \& Schachter, H. (1966). J. biol. Chem. 241, 5408.

Lissitzky, S., Rolland, M. \& Bergot, J. (1965a). Biochim. biophys. Acta, 111, 543.

Lissitzky, S., Rolland, M., Reynaud, J., Savary, J. \& Lasry, S. (1968). Europ. J. Biochem. 4, 464.
Lissitzky, S., Roques, M., Torresani, J. \& Simon, C. (1965b). Bull. Soc. Chim. biol., Paris, 47, 1999.

Lissitzky, S., Roques, M., Torresani, J., Simon, C. \& Bouchilloux, S. (1964). Biochem. biophys. Res. Commun. 16, 249.

Lowry, O. H., Rosebrough, N. J., Farr, A. L. \& Randall, R. J. (1951). J. biol. Chem. 193, 265.

Martin, R. G. \& Ames, B. N. (1961). J. biol. Chem. 236, 1372.

Nadler, N. J., Young, B. A., Leblond, C. P. \& Mitmaker, B. (1964). Endocrinology, 74, 333.

Nunez, J., Mauchamp, J., Macchia, V. \& Roche, J. (1965). Biochim. biophys. Acta, 107, 247.

Nunez, J., Pavlovic-Hournac, M., Rappaport, L. \& Roche, J. (1967). Bull. Soc. Chim. biol., Paris, 49, 1295.

Pierce, J. G., Ravitch, A. B., Brown, D. N. \& Stanley, P. G. (1965). Biochim. biophys. Acta, 111, 247.

Robbins, J. \& Rall, J. E. (1960). Physiol. Rev. 40, 415.

Salvatore, G., Aloj, S., Salvatore, M. \& Edelhoch, H. (1967). J. biol. Chem. 242, 5002.

Salvatore, G., Salvatore, M., Cahnmann, H. J. \& Robbins, J. (1964). J. biol. Chem. $239,3267$.

Seed, R. W. \& Goldberg, I. H. (1963). Proc. nat. Acad. Sci., Wash., 50, 275.

Seed, R. W. \& Goldberg, I. H. (1965). J. biol. Chem. 240, 764.

Sellin, H. G. \& Goldberg, I. H. (1965). J. biol. Chem. 240, 774.

Spiro, M. J. \& Spiro, R. G. (1967). Proc. 7th int. Congr. Biochem., Tokyo, p. 710.

Spiro, R. G. (1965). J. biol. Chem. 240, 1603.

Spiro, R. G. (1966). In Methods in Enzymology, vol. 8, p. 38. Ed. by Colowick, S. P. \& Kaplan, N. O. New York: Academic Press Inc.

Spiro, R. G. \& Spiro, M. J. (1965a). J. biol. Chem. 240, 997.

Spiro, R. G. \& Spiro, M. J. (1965b). Proc. 5th int. Thyroid Conf., Rome, p. 157. New York: Academic Press Inc.

Spiro, R. G. \& Spiro, M. J. (1966). J. biol. Chem. 241, 1271.

Thomson, J. A. \& Goldberg, I. H. (1968). Endocrinology, $82,805$.

Ujejski, L. \& Glegg, R. E. (1955). Canad. J. Biochem. Physiol. 33, 199.

Umbreit, W. W., Burris, R. H. \& Stauffer, J. F. (1957). Manometric Techniques, p. 149. Minneapolis: Burgess Publishing Co.

Vecchio, G., Salvatore, M. \& Salvatore, G. (1966). Biochem. biophys. Res. Commun. 25, 402. 